\title{
Produção dos róticos em sequências consonantais [CR] e [RC] no português de contato com o pomerano
}

\author{
Production of the rhotics in consonant sequences [CR] and $[R C]$ in the Portuguese of \\ contact with Pomeranian
}

\author{
Felipe Bilharva da Silva* \\ Instituto Federal Sul-rio-grandense de Pelotas \\ Pelotas, Rio Grande do Sul, Brasil
}

\begin{abstract}
Resumo: O presente trabalho investiga a influência do pomerano na produção dos segmentos róticos em sequências consonantais [CR] e [RC] no português falado no município de São Lourenço do Sul (RS). Para tanto, são analisadas as produções de dez participantes, cinco delas bilíngues, falantes do português e do pomerano, e cinco monolíngues, falantes do português, constituindo o grupo controle. Foram realizados três experimentos para produção dos dados: descrição de imagens, nomeação de imagens e leitura de palavras. Esses experimentos perpassavam um continuum de estilo, no qual o primeiro emulava um ambiente mais naturalístico, a fim de observar um registro mais natural da fala; o segundo e o terceiro experimentos, por sua vez, apresentavam um controle mais experimental, em que os itens lexicais foram previamente selecionados, distribuídos de acordo com as variáveis posição do rótico, ponto de articulação de C, vozeamento de C, tonicidade e vogal nuclear da sílaba. Assim, obteve-se um número de produções regular entre as participantes, bem como controlou-se a atuação de variáveis linguísticas. Os resultados revelaram emprego quase categórico do tepe na posição pré-vocálica, tanto no grupo bilíngue quanto no monolíngue. Na posição pós-vocálica, por outro lado, verificou-se que, enquanto as monolíngues produziram número elevado de tepes, as bilíngues demonstraram grande variação, produzindo em número considerável de vibrantes múltiplas, aproximantes e fricativas palato-alveolares desvozeadas. O Teste de Qui-Quadrado com resíduos padronizados detectou uma correlação entre o emprego dessas variantes e o grupo bilíngue. Além disso, detectou uma correlação entre o emprego do tepe e o grupo monolíngue. Propôs-se, como conclusão, que o pomerano exerceu influência sobre esses resultados, dado que, na língua de imigração, o tepe não ocupa a posição pós-vocálica, o que pode ter influenciado os falantes a evitar o emprego dessa variante na posição de coda.
\end{abstract}

Palavras-chave: Pomerano. Róticos. Línguas de imigração germânicas. Fonética e Fonologia. Grupos consonantais.

\begin{abstract}
The present work investigates the influence of Pomeranian in the production of rhotic segments in consonant sequences [CR] and [RC] in Portuguese spoken in the municipality of São Lourenço do Sul (RS). For that, the productions of ten participants are analyzed, five of them bilingual, speakers of Portuguese and Pomeranian, and five monolinguals, speakers of Portuguese, constituting the control group. Three experiments were carried out to produce the data: image description, image naming and word reading. These experiments passed through a continuum of style, in which the first emulated a more naturalistic environment, in order to observe a more natural record of speech; the second and the third experiments, in turn, presented a more experimental control, in which the lexical items were previously selected, distributed according to the variables rhotic position, $C$ place of articulation, $C$ voicing, tonicity and nuclear vowel of the syllable. Thus, a regular number of productions was obtained among the participants, as well as the performance of linguistic variables. The results revealed an almost categorical use of taps in the pre-vowel position, both in the bilingual and monolingual groups. In the post-vowel position, on the other hand, it was found that, while the monolinguals produced a high number of taps, the bilinguals showed great variation, producing a considerable number of trills, approximants and voiceless palatoalveolar fricatives. The Chi-Square Test with standardized residues detected a correlation between the use of these variants and the bilingual group. In addition, it detected a correlation between the use of tap and the monolingual group. As a conclusion, it was proposed that
\end{abstract}

\footnotetext{
* Doutor em Linguística pela Pontifícia Universidade Católica do Rio Grande do Sul (PUCRS). Professor Doutor - Instituto Federal Sul-rio-grandense - Campus Pelotas, Pelotas, Rio Grande do Sul, Brasil. E-mail: felipebilharva@yahoo.com.br.
} 
Pomeranian influenced these results, given that, in the language of immigration, taps do not occupy the postvowel position, which may have influenced speakers to avoid using this variant in the position of coda.

Keywords: Pomeranian. Rhotics. German Immigration Languages. Phonetics and Phonology. Consonantal clusters.

\section{INTRODUÇÃO}

A partir da segunda metade do século XIX, com a iminente queda do regime escravagista no Brasil, iniciou-se um processo de incentivo à imigração de povos europeus e asiáticos para o território nacional, como uma forma de substituir a mão de obra escrava. Havia, na época, interesse latente da burguesia brasileira em ocupar o território nacional e, posteriormente, adquirir força trabalhadora qualificada especialmente para atuar nas lavouras de café. A migração para o Brasil também tinha como função solucionar o problema da superpopulação na Europa, que fazia com que milhares de trabalhadores enfrentassem grave crise de desemprego (CUNHA, 2003). A convergência de interesses brasileiros e europeus fez com que, entre os anos de 1820 e 1900, 2.111 .496 imigrantes de diversas nacionalidades desembarcassem no Brasil (IBGE, 2000).

Dentre os povos que imigraram, estavam os provenientes da região da Pomerânia, província situada a nordeste da Alemanha e a noroeste da Polônia, às margens do Mar Báltico. Apesar de os dados reais sobre o número de imigrantes pomeranos não serem precisos, Tressmann (1998) e Bremenkamp (2014) afirmam que os números aproximaram-se de 30.000. A maior parte desses trabalhadores instalou-se no estado do Espírito Santo, no qual os pomeranos constituem atualmente o maior grupo $(56 \%)$ entre os imigrantes germânicos (TRESSMANN, 1998), a ponto de a língua pomerana ser considerada língua franca entre os teuto-brasileiros, como explica Bremenkamp et. al. (2017).

No Rio Grande do Sul, a imigração pomerana ocorreu em menor número e em uma região específica do estado, localizada na zona sul, na chamada Serra dos Tapes. Os primeiros imigrantes chegaram ao estado no ano de 1858, e hoje são encontradas comunidades pomeranas nos municípios de São Lourenço do Sul, Canguçu, Arroio do Padre, Turuçu, entre outros.

Um fato que diferencia a comunidade pomerana dos demais grupos teutobrasileiros instalados no Brasil diz respeito à extinção de sua região de origem no continente europeu. Após a II Guerra Mundial, como explica Rölke (1996), a província da Pomerânia foi extinta, como consequência da Conferência de Potsdam. Seu território foi dividido entre a Polônia, que ficou com aproximadamente $80 \%$ do território, e a Alemanha, na qual hoje integra o estado de Mecklemburgo-Pomerânia Ocidental. Após a invasão do Exército Vermelho na região nordeste da Alemanha, um milhão e oitocentos mil pomeranos orientais - praticamente a totalidade da população - fugiram da região, sendo que aproximadamente quinhentos mil morreram na fuga. Esse processo fez com que a cultura e a língua pomerana praticamente desaparecessem da Europa, permanecendo vivas apenas nos países que sediaram processos migratórios no século XIX, como o Brasil, a Austrália e os Estados Unidos. 
Diferentes fatores foram responsáveis pela preservação da língua pomerana no Brasil, resistindo ao processo de extinção pelo qual outras línguas de imigração passaram. De acordo com Vandresen (2008), um desses fatores foi o isolamento geográfico. Segundo o autor, o município de Arroio do Padre, por exemplo, encontrava-se isolado até o ano de 1937, quando o processo de Nacionalização promovido por Getúlio Vargas obrigou a abertura das comunidades germânicas e fez com que o português adentrasse esses territórios. Outro ponto relevante para a preservação do pomerano até os dias atuais foi a religião, já que os pomeranos eram majoritariamente protestantes, e sua língua era considerada a língua da fé.

Esses e outros fatores fizeram com que o pomerano fosse preservado e empregado de forma regular até os dias de hoje, tornando possível a caracterização dos municípios sede de colonização pomerana como ambientes de diglossia com bilinguismo, nos termos de Ferguson (1959) e Fishman (1979). Nesse cenário, a língua portuguesa empregada pelos falantes preserva peculiaridades que podem ser associadas à presença da língua de imigração, como a troca entre vibrantes múltiplas e simples, a dessonorização de obstruintes e a redução de ditongos nasais, características apontadas por autores como Vandresen (2008) e Prade (2003).

Dentre essas produções características, uma classe de segmentos que tem sido alvo de diferentes estudos é a dos róticos. Reinecke (2006), por exemplo, ao investigar a produção desses segmentos em posição intervocálica, verifica a realização de nove variantes róticas situadas entre o r-simples e o r-duplo, em duas comunidades falantes do alemão e do pomerano, situadas nos municípios de Blumenau (SC) e Lages (SC). A autora associa a produção dessas variantes a variáveis como a frequência do item lexical e a classe de palavras. Por sua vez, Bilharva da Silva (2015), analisando dados de fala, escrita e percepção de estudantes bilíngues (português/pomerano) em etapa inicial de alfabetização, igualmente identifica variação entre as produções de r-simples e r-duplo. Além disso, detecta, no teste de percepção, maior dificuldade dos bilíngues no reconhecimento de pares mínimos envolvendo contrastes entre os róticos, acompanhada de maior número de erros ortográficos na grafia de 'rr'.

Levando em consideração esses aspectos, no presente trabalho ${ }^{1}$, investigamos a produção dos segmentos róticos em grupos consonantais dotados de tepes em posição pré-vocálica - como em prato - e pós-vocálica - como em carta -, por falantes bilíngues do pomerano e do português e por falantes monolíngues do português, nos municípios de São Lourenço do Sul, sede de colonização pomerana no Rio Grande do Sul, e Pelotas. Nesse sentido, a pesquisa busca lançar um olhar sobre um contexto silábico geralmente não abordado pelos estudos mencionados anteriormente, que focam sua análise na posição intervocálica, na qual $r$-forte e r-fraco estabelecem contraste fonológico no português. Ao abordar um contexto não contrastivo, espera-se verificar uma influência mais acentuada do pomerano no português, dado que a ausência de um contraste fonológico oferece, em tese, maior liberdade para que o sistema linguístico do pomerano exerça influência sobre o português. Além disso, a seleção por grupos consonantais

${ }^{1}$ O presente trabalho foi realizado com apoio da Coordenação de Aperfeiçoamento de Pessoal Nível Superior - Brasil (CAPES) - Código de Financiamento 001. 
justifica-se pelo fato de que constituem sequências de articulação complexa, como o comprovam dados de aquisição da linguagem (MATZENAUER; BONILHA, 2003), que apontam esse contexto silábico como uma das aquisições mais tardias do português. Dada essa complexidade, espera-se verificar um ambiente mais propício a instabilidades articulatórias, a partir das quais a influência do pomerano pode revelar-se.

Dessa forma, espera-se verificar se falantes bilíngues apresentam comportamento distinto quanto à produção dos róticos no português, tendo como motivação o contato linguístico com o pomerano. Para proceder tal investigação, na seção 2, estabelecemos uma comparação estrutural entre pomerano e português, mapeando os contextos nos quais os róticos apresentam comportamento distinto. $\mathrm{Na}$ sequência, na seção 3, apresentamos os aspectos metodológicos do estudo, descrevendo os instrumentos de coleta de dados e os procedimentos estatísticos utilizados. $\mathrm{Na}$ seção 4, apresentamos os principais resultados do estudo, traçando uma comparação entre os desempenhos de monolíngues e bilíngues. Por fim, na seção 5, traçamos algumas interpretações dos resultados e chegamos às conclusões do estudo.

\section{COMPARAÇÃO ESTRUTURAL ENTRE POMERANO E PORTUGUÊS}

A análise comparativa proposta neste trabalho ampara-se nas discussões sobre o contato linguístico do ponto de vista estrutural, uma abordagem cujas bases foram assentadas por Weinreich (1963 [1953]). A proposta realizada pelo autor adota como conceito chave a ideia de interferência: "instâncias de desvio das normas de cada uma das línguas que ocorrem na fala de bilíngues como resultado de sua familiaridade com mais de uma língua, ou seja, como resultado do contato linguístico" (WEINREICH, 1963 [1953], p. 1, tradução nossa ${ }^{2}$. Para Weinreich (1963 [1953]), o objeto de investigação do linguista seria exatamente o impacto desse fenômeno.

Segundo Weinreich (1963 [1953]), a interferência não constituiria apenas uma transferência de um dado elemento de um sistema linguístico para outro, mas atuaria como o catalisador de uma reorganização no novo sistema, atingindo aspectos estruturais da gramática, como a fonologia, a morfologia e o léxico. Nesse sentido, "quanto maiores as diferenças entre as duas línguas, isso é, quanto mais formas e padrões mutuamente exclusivos, maior é o problema de aprendizado e a área potencial de interferência" (WEINREICH, 1963 [1953], p. 1, tradução nossa ${ }^{3}$ ).

O conceito de interferência proposto por Weinreich (1963 [1953]) passou a ser reinterpretado por autores como Matras (2011), a partir da noção de empréstimo. Para o autor, o empréstimo consistiria na "remoção de uma linha demarcatória invisível que separa subsistemas dentro das propriedades linguísticas (ou das 'línguas' do falante)" (MATRAS. 2011, p. 204, tradução nossa ${ }^{4}$ ). Assim, o empréstimo seria ocasionado pela

\footnotetext{
2 "Those instances of deviation from the norms of either language which occur in the speech of bilinguals as a result of their familiarity with more than one language, i.e. as a result of language contact."

3 "The greater the difference between the systems, i.e. the more numerous the mutually exclusive forms and patterns in each, the greater is the learning problem and the potential area of interference."

4 "(...) removal of an invisible demarcation line that separates subsets within the linguistic properties (os the speaker's 'languages').”
} 
generalização no emprego de uma dada propriedade, que poderia ser um detalhe fonético, um fonema ou estruturas maiores, como um item lexical ou um padrão sintático.

Do ponto de vista metodológico, a investigação de empréstimos fônicos de duas línguas em contato, segundo Weinreich (1963 [1953]), deveria ser estabelecida por meio da descrição do sistema 1 e do sistema 2, e, a partir dessas descrições, da identificação dos fonemas e contrastes fonológicos que estão presentes em uma língua e ausentes na outra. A dificuldade na produção desses fonemas ausentes não é sempre a mesma, entretanto. A comparação entre as línguas demonstra, segundo o autor, que certos fonemas, apesar de ausentes em um dos sistemas, podem ser produzidos dedutivamente porque os traços articulatórios que os compõem estão presentes em outros sons da língua.

Buscando convergir com a proposta metodológica de Weinreich (1963 [1953]), neste trabalho estabelecemos uma comparação entre o português falado no município de Pelotas, cidade na qual as participantes monolíngues, pertencentes ao grupo controle, nasceram e residem, e o pomerano falado no município de Santa Maria do Jetibá (ES) ${ }^{5}$, a partir da descrição fonético-fonológica da língua de imigração realizada por Schaeffer (2012). Além de estabelecer uma comparação entre os róticos presentes nos sistemas fonético e fonológico das duas línguas, é necessário lançar luz sobre o comportamento fonotático desses segmentos, a fim de avaliar se podem ocupar as mesmas posições silábicas e combinar-se com os mesmos segmentos. Assim, avaliaremos os contextos silábicos CRV - consoante/rótico/vogal - e VRC - vogal/rótico/consoante -, contextos alvo da análise aqui proposta. A distribuição estrutural das duas línguas, nos contextos discutidos, é apresentada no Quadro 1.

Quadro 1 - Distribuição dos fones do pomerano e do português pelotense nos contextos CRV e VRC

\begin{tabular}{|c|c|c|c|c|}
\hline & \multicolumn{2}{|c|}{ Pomerano (S. M. Jetibá) } & \multicolumn{2}{|c|}{ Português (Pelotas) } \\
\hline Fone & Ataque complexo & Coda simples & Ataque complexo & Coda simples \\
\hline [p] & ['prava] & ['วp] & ['prato] & $!$ \\
\hline [b] & ['broud] & ['lu:b] & ['broua] & $!$ \\
\hline [t] & ['trext] & - & ['tragu] & - \\
\hline [d] & [hi'drẽıng] & ['hyd] & ['drage] & $!$ \\
\hline [k] & ['krout] & ['buk] & ['kravu] & ! \\
\hline [g] & ['gras] & ['deg] & ['grote] & $!$ \\
\hline$\left[k^{h}\right]$ & [tehalsis'k $k^{h}$ roud] & ['jak $\left.{ }^{\mathrm{h}}\right]$ & $!$ & $!$ \\
\hline [f] & ['frixt] & [havf] & ['fraku] & $!$ \\
\hline [v] & $!$ & ['Jruv] & ['livro] & - \\
\hline$[x]$ & - & ['dax] & - & $!$ \\
\hline [6] & - & ['rouf] & - & ! \\
\hline [r] & ['broud] & ! & ['preto] & ['karta] \\
\hline
\end{tabular}

Fonte: o autor (2020), com base em Schaeffer (2012)

! : célula não preenchida em apenas uma das línguas

- : célula não preenchida em nenhuma das línguas

\footnotetext{
${ }^{5}$ Desconhecemos descrições fonético-fonológicas do pomerano falado na Serra dos Tapes, motivo que nos leva a adotar o trabalho de Schaeffer (2012), ainda que considerando as possíveis distinções entre a variedade capixaba e a variedade gaúcha. No trabalho de Schaeffer (2012), a autora coletou dados de quatro participantes, com idades entre 11 e 48 anos, todos falantes de pomerano como língua dominante. A análise foi realizada com base no modelo estruturalista de Pike (1948).
} 
A análise comparativa possibilitada pelo Quadro 1 revela algumas simetrias e assimetrias estruturais entre o padrão fonotático das sequências CRV e VRC nos dois sistemas linguísticos. De acordo com a proposta de Weinreich (1963 [1953]), as assimetrias entre os dois sistemas em contato podem exercer complexidades para o falante bilíngue, que necessita dar conta de lacunas em um dos dois sistemas.

Não nos ocuparemos, nesta discussão, da possibilidade de consoantes obstruintes ocuparem a posição de coda simples no pomerano, dado que tal verificação extrapola os objetivos deste estudo. Dessa forma, um primeiro ponto de comparação diz respeito às simetrias verificadas entre português e pomerano na posição de ataque complexo. É possível observar que as consoantes $[\mathrm{p}, \mathrm{b}, \mathrm{t}, \mathrm{d}, \mathrm{k}, \mathrm{g}, \mathrm{f}]$ podem ocupar a primeira posição do ataque em ambas as línguas, acompanhadas pelo tepe alveolar na segunda posição. Há apenas um desequilíbrio em cada sistema: no português, a fricativa [v] pode ocupar a primeira posição do grupo, ao contrário do pomerano; no pomerano, por sua vez, temos a possibilidade da plosiva aspirada $\left[\mathrm{k}^{\mathrm{h}}\right]$ ocupar a primeira posição, ao contrário do português, que não apresenta consoantes aspiradas.

$\mathrm{Na}$ comparação entre os padrões de coda ocupada por róticos nos dois sistemas, as diferenças mais relevantes podem ser verificadas. No pomerano, essa posição é preenchida pelas fricativas velar $[\mathrm{x}]$ e glotal [h], ao contrário do português falado em Pelotas, que a ocupa com o tepe [r]. Verifica-se assim uma lacuna na comparação entre as línguas, que pode desencadear complexidades à produção dos bilíngues, especialmente porque a articulação do tepe constitui uma das mais complexas do português brasileiro. Miranda (1996) e Bonilha (2004), por exemplo, apontam esse como o último segmento a ser produzido por crianças em etapa de aquisição da linguagem. Logo, pode-se tomar como hipótese principal deste trabalho que a posição de coda constituirá o contexto de maior instabilidade para os falantes bilíngues estudados.

É importante afirmar que a ausência de tepes em posição pós-vocálica no pomerano, apontada por Schaeffer (2012), não parece categórica. Mesmo nos dados da autora é possível verificar algumas ocorrências dessas produções. Benincá (2008), por sua vez, tomando por base o Dicionário Enciclopédico Pomerano-Português (TRESSMANN, 2006), aponta que o tepe pode ocupar essa posição na língua. Entretanto, observando os dados apresentados em ambos os trabalhos, detecta-se uma baixa frequência dessas ocorrências, o que permite levantar a hipótese de que tais ocorrências justificam-se por uma variação motivada pelo contato com o português, não constituindo um padrão recorrente na língua de imigração. Argumento para essa hipótese pode ser encontrado nas realizações da palavra "farmácia", nos dados de Schaeffer (2012):

\section{Informante 1: [far'mase] \\ Informante 2: [fax'masie] \\ Informante 3: [far'masie]}

Nos dados apresentados, pode-se verificar que a produção em pomerano de "farmácia" foi ancorada na forma do português, um tipo de fenômeno detectado nas línguas de imigração no Brasil intitulado por Prade (2003) de dentsch-brasilianische 
Sprachmischung. Nesse fenômeno, o falante aplica substantivos do português na língua de imigração, especialmente aqueles que se referem a conceitos modernos, que não apresentam uma forma própria na língua do falante. O elemento digno de nota no dado discutido, entretanto, é a produção do participante 2, que parece adaptar a forma aportuguesada ao padrão fonotático do pomerano, no qual a fricativa velar, [x], ocorre na posição final de sílaba, ao contrário do tepe, conforme observado no Quadro 1. As informantes 1 e 3 , por sua vez, preservam o padrão fonotático do português, produzindo o tepe na posição pós-vocálica. Dessa forma, apesar de o tepe em coda ser efetivamente produzido em um item lexical do pomerano - afinal, a palavra "farmácia" já faz parte do léxico do pomerano em Santa Maria do Jetibá -, essa produção está claramente ancorada no português, não constituindo um padrão regular da língua de imigração. Com base nesses dados, podemos defender que o tepe não ocupa a coda no pomerano.

\section{METODOLOGIA}

Para a realização do estudo, foram selecionadas dez participantes, cinco bilíngues moradoras do município de São Lourenço do Sul, sede de imigração pomerana, e cinco monolíngues moradoras de Pelotas, constituindo o grupo controle. As duas cidades, situadas na região sul do Rio Grande do Sul, distam uma da outra $72,7 \mathrm{~km}$. A Figura 1 mostra suas localizações no mapa gaúcho.

Figura 1 - Localização dos municípios de Pelotas e São Lourenço do Sul no mapa do Rio Grande do Sul

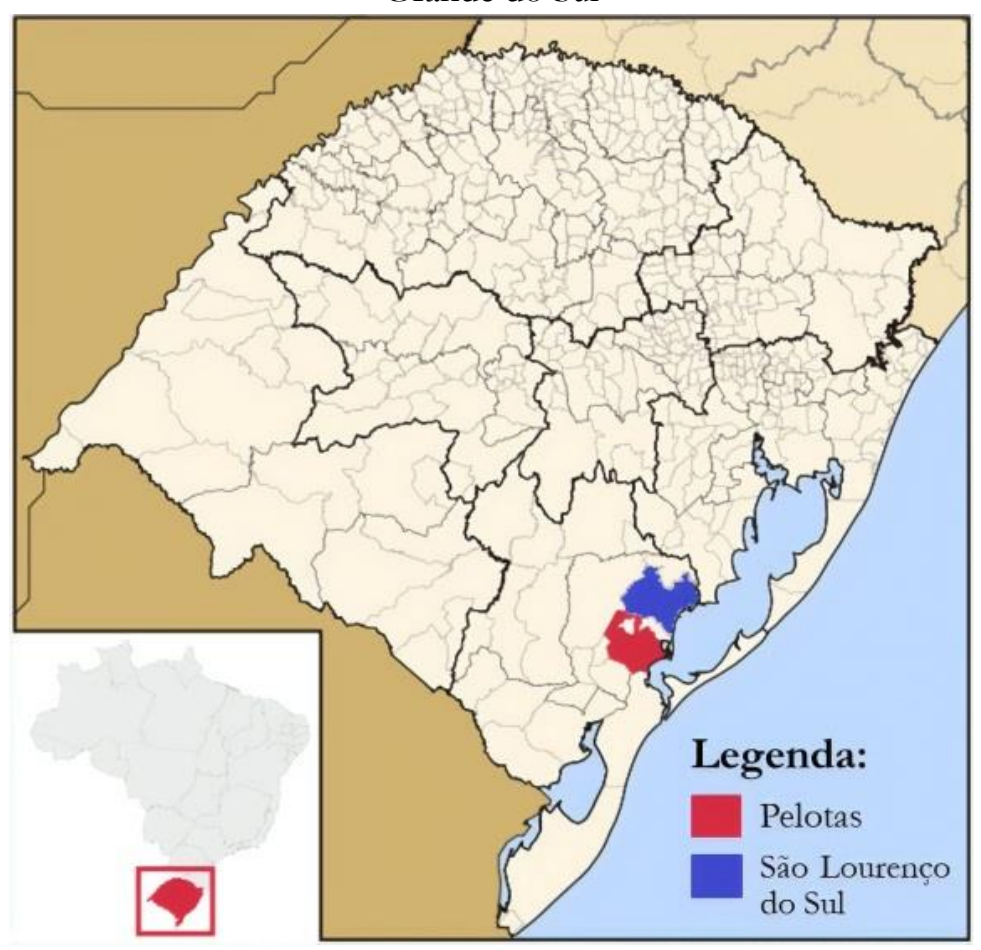

Fonte: Rio Grande do Sul (2020) 
A fim de minimizar a atuação de variáveis sociais como gênero e idade - que não foram investigadas neste estudo -, tais variáveis foram uniformizadas, sendo selecionadas apenas mulheres com idades superiores a 42 anos. Outras variáveis cuja influência poderia ser relevante, como escolaridade e profissão, não foram controladas, dado que sua uniformização reduziria o número de participantes disponível. $O$ perfil social das participantes é apresentado no Quadro 2.

Quadro 2 - Perfil social das participantes do estudo

\begin{tabular}{|c|c|c|c|c|c|c|}
\hline Nome & Grupo & Idade & $\begin{array}{c}\text { Local de } \\
\text { nascimento }\end{array}$ & Profissão & Escolaridade & $\begin{array}{c}\text { Cidades em que } \\
\text { morou }\end{array}$ \\
\hline $\mathbf{M}$ & Monolíngue & 60 anos & Pelotas & Balconista & E. Médio completo & Pelotas \\
\hline $\mathbf{E}$ & Monolíngue & 69 anos & Pelotas & Aposentada & E. Médio completo & Pelotas \\
\hline I & Monolíngue & 49 anos & $\begin{array}{c}\text { Canguçu } \\
\text { (mudou-se } \\
\text { para Pelotas } \\
\text { com um ano) }\end{array}$ & Assistente social & Ensino superior & $\begin{array}{c}\text { Canguçu, Pelotas, } \\
\text { Porto Alegre, entre } \\
\text { outras }\end{array}$ \\
\hline $\mathbf{A}$ & Monolíngue & 56 anos & Pelotas & Dona de casa & $\begin{array}{l}\text { Fundamental } \\
\text { incompleto }\end{array}$ & Pelotas \\
\hline $\mathbf{R}$ & Monolíngue & 47 anos & Pelotas & Microempresária & $\begin{array}{l}\text { E. Médio } \\
\text { incompleto }\end{array}$ & Pelotas \\
\hline EL & Bilíngue & 60 anos & $\begin{array}{c}\text { São Lourenço } \\
\text { do Sul }\end{array}$ & Comerciante & E. Médio completo & $\begin{array}{c}\text { São Lourenço do } \\
\text { Sul, Pelotas }\end{array}$ \\
\hline G & Bilíngue & 55 anos & $\begin{array}{c}\text { São Lourenço } \\
\text { do Sul }\end{array}$ & $\begin{array}{l}\text { Servidora } \\
\text { pública }\end{array}$ & Ensino superior & $\begin{array}{c}\text { São Lourenço do } \\
\text { Sul, Pelotas }\end{array}$ \\
\hline IL & Bilíngue & 60 anos & $\begin{array}{c}\text { São Lourenço } \\
\text { do Sul }\end{array}$ & Agricultora & E. Médio completo & $\begin{array}{c}\text { São Lourenço do } \\
\text { Sul, Pelotas }\end{array}$ \\
\hline $\mathbf{L}$ & Bilíngue & 42 anos & $\begin{array}{c}\text { São Lourenço } \\
\text { do Sul }\end{array}$ & Dona de casa & $\begin{array}{l}\text { Fundamental } \\
\text { incompleto }\end{array}$ & $\begin{array}{c}\text { São Lourenço do } \\
\text { Sul }\end{array}$ \\
\hline $\mathbf{V}$ & Bilíngue & 65 anos & $\begin{array}{c}\text { São Lourenço } \\
\text { do Sul }\end{array}$ & Aposentada & $\begin{array}{l}\text { Fundamental } \\
\text { incompleto }\end{array}$ & $\begin{array}{c}\text { São Lourenço do } \\
\text { Sul }\end{array}$ \\
\hline
\end{tabular}

Fonte: o autor (2020)

Por outro lado, o grau de contato com a língua de imigração das moradoras de São Lourenço do Sul foi controlado. Para tanto, foram selecionadas apenas falantes que tem a língua pomerana como a primeira adquirida, tendo aprendido português apenas na idade de ingresso escolar. Além disso, todas as participantes falavam pomerano diariamente na época de realização das coletas de dados. O Quadro 3 sintetiza as informações sobre o perfil linguístico das participantes bilíngues. 
Quadro 3 - Perfil linguístico das participantes bilíngues

\begin{tabular}{|c|c|c|c|c|}
\hline $\begin{array}{l}\text { No } \\
\text { me }\end{array}$ & Línguas faladas & $\begin{array}{l}\text { Idade com que as } \\
\text { aprendeu }\end{array}$ & $\begin{array}{c}\text { Contextos de uso na } \\
\text { infância }\end{array}$ & Uso das línguas atualmente \\
\hline EL & $\begin{array}{l}\text { Pomerano, } \\
\text { português, alemão, } \\
\text { inglês (básico) }\end{array}$ & $\begin{array}{l}\text { pomerano e alemão: L1; } \\
\text { português: } 7 \text { anos }\end{array}$ & $\begin{array}{l}\text { alemão e pomerano } \\
\text { eram falados com os } \\
\text { pais; português: escola }\end{array}$ & $\begin{array}{l}\text { pomerano: no trabalho; } \\
\text { português: em casa. }\end{array}$ \\
\hline G & $\begin{array}{l}\text { Pomerano, } \\
\text { português }\end{array}$ & $\begin{array}{l}\text { pomerano: L1; português: } \\
7 \text { anos }\end{array}$ & $\begin{array}{l}\text { pomerano: casa e } \\
\text { comunidade; português: } \\
\text { escola }\end{array}$ & $\begin{array}{l}\text { português: com a família; } \\
\text { pomerano: em encontros com } \\
\text { outros falantes. Uso diário de } \\
\text { ambas as línguas. }\end{array}$ \\
\hline IL & $\begin{array}{l}\text { Pomerano, } \\
\text { português, alemão } \\
\text { (apenas compreende) }\end{array}$ & $\begin{array}{l}\text { pomerano: L1; português: } \\
8 \text { anos; alemão: } 21 \text { anos }\end{array}$ & $\begin{array}{l}\text { pomerano: casa e } \\
\text { comunidade; português: } \\
\text { escola }\end{array}$ & $\begin{array}{l}\text { fala mais pomerano do que } \\
\text { português. }\end{array}$ \\
\hline $\mathbf{L}$ & $\begin{array}{l}\text { Pomerano, } \\
\text { português }\end{array}$ & $\begin{array}{l}\text { pomerano: L1; português: } \\
7 \text { anos }\end{array}$ & $\begin{array}{l}\text { pomerano: casa e } \\
\text { comunidade; português: } \\
\text { escola }\end{array}$ & $\begin{array}{l}\text { pomerano: casa; português: no } \\
\text { trabalho e com quem não fala } \\
\text { pomerano. }\end{array}$ \\
\hline V & $\begin{array}{l}\text { Pomerano, } \\
\text { português }\end{array}$ & $\begin{array}{l}\text { pomerano: L1; português: } \\
7 \text { anos }\end{array}$ & $\begin{array}{l}\text { pomerano: casa e } \\
\text { comunidade; português: } \\
\text { escola }\end{array}$ & $\begin{array}{l}\text { português usado apenas com } \\
\text { quem não fala pomerano, em } \\
\text { poucas ocasiões. }\end{array}$ \\
\hline
\end{tabular}

Fonte: o autor (2020)

Com base nas informações apresentadas no Quadro 2 e nas definições de bilinguismo calcadas no uso, propostas por Grosjean (2008; 2010), definimos o pomerano como língua dominante das participantes bilingues investigadas.

Para a coleta de dados, foram desenvolvidos três instrumentos para a eliciação das palavras dotadas do contexto alvo da pesquisa. Esses instrumentos foram elaborados de maneira a percorrer um continuum de estilo que parte de um instrumento mais naturalístico - descrição de imagens (experimento 1) -, passa por um nível de controle intermediário - nomeação de imagens (experimento 2) - e chega a um elevado nível de controle - leitura de palavras (experimento 3).

No primeiro experimento, cujo objetivo era observar a produção dos róticos em um ambiente mais próximo à fala natural das participantes, eram observadas e descritas cinco figuras, extraídas do livro Avaliação Fonológica da Criança (YAVAS; HERNANDORENA; LAMPRECHT, 1991), uma obra voltada para estudos de aquisição da linguagem que apresenta elementos cujos nomes contêm diferentes contextos segmentais e silábicos. Além das imagens presentes no livro - zoológico, cožinha, sala, banheiro e veículos -, foram digitalmente inseridos elementos adicionais, como "tartaruga", "circo" e "borboleta", a fim de aumentar o número de palavras dotadas de sequências consonantais, como mostra a Figura 2. 
Figura 2 - Figuras digitalmente inseridas na descrição de imagens

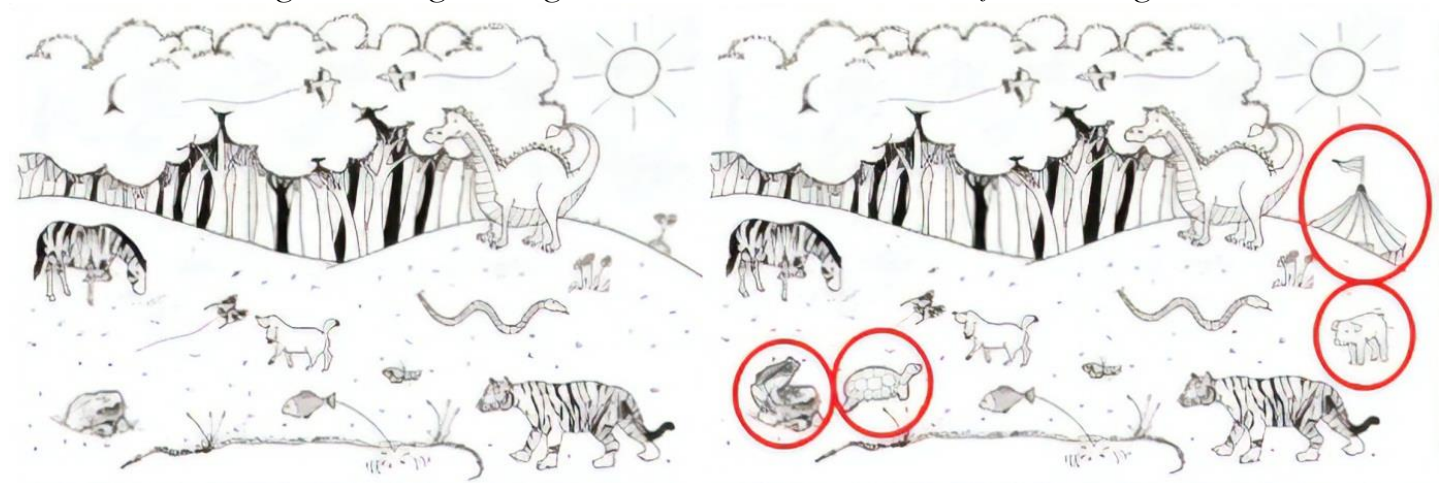

Fonte: Bilharva da Silva (2019), com base em Yavas, Hernandorena e Lamprecht (1991)

Nos experimentos 2 e 3, os estímulos foram integralmente controlados, ou seja, as participantes deveriam produzir itens lexicais específicos. Assim, optou-se por selecionar palavras dissilábicas, paroxítonas, com o rótico inserido na sílaba tônica ${ }^{6}$, como em "cravo" e "gordo". A fim de controlar o padrão entoacional e regularizar os controles fonéticos além dos limites da palavra, nos experimentos 2 e 3, os estímulos foram produzidos no interior da frase-veículo Digo cada vez, utilizada por Romero (2008). Essa frase foi selecionada por apresentar um segmento plosivo desvozeado após a palavra-alvo, o que reduz os efeitos de coarticulação. Igualmente com a finalidade de reduzir a coarticulação, sempre que possível eram selecionadas palavras nas quais a consoante vizinha ao tepe no grupo era plosiva, como em "preto" e "verbo". Por fim, as palavras foram controladas de acordo com sonoridade - vozeada/desvozeada -, ponto de articulação da consoante vizinha ao tepe - labial/coronal/dorsal -, vogal nuclear - [a, $\mathrm{e}, \varepsilon, \mathrm{i}, \mathrm{o}, \mathrm{\rho}, \mathrm{u}]$-, tonicidade - átona/tônica - e posição do rótico - pré-vocálica/pósvocálica.

Assim, no experimento 2, eram apresentadas na tela do tablet 70 imagens cujos nomes deveriam ser produzidos no interior da frase-veículo, metodologia que também foi empregada no experimento 3, com a diferença que, neste experimento, eram apresentadas as representações ortográficas dos itens lexicais desejados, que deveriam ser lidas pelas participantes, igualmente na frase-veículo?

As coletas de dados ocorreram nas casas das participantes, em ambiente de relativo silêncio. Todos leram e assinaram o Termo de Consentimento Livre e Esclarecido,

\footnotetext{
${ }^{6}$ Com exceção de um grupo de palavras dotadas de rótico na sílaba átona, como "cruel" e "cartão", selecionadas para avaliar a atuação da tonicidade.

${ }^{7} \mathrm{O}$ experimento 3 totalizou 96 estímulos, sendo 70 deles os mesmos já apresentados no experimento 2 e 26 inéditos. A repetição das mesmas palavras em dois experimentos teve como objetivo avaliar se a presença da representação ortográfica desencadearia mudanças na forma como uma palavra é produzida.
} 
viabilizando sua participação no estudo ${ }^{8}$. Para a gravação dos estímulos, foi utilizado um gravador digital Zoom H4N, e, para a apresentação das imagens, foi utilizado um tablet equipado com o software Microsoft PowerPoint. Ao final do estudo, foram eliciadas 2.171 palavras dotadas do contexto alvo por todas as participantes. A decisão pela variante empregada foi tomada a partir de uma conjuntura entre critérios auditivos e acústicos. Inicialmente, os dados investigados foram categorizados com base na análise de outiva, e, em um segundo momento, a análise acústica foi empregada a fim de corroborar as decisões anteriormente tomadas. Para a investigação acústica, foi utilizado o software Praat, versão 6.0.21.

Os dados obtidos foram analisados estatisticamente com o recurso do software SPSS Statistics, versão 20.0. Nos testes realizados, buscou-se avaliar uma correlação entre o emprego das variantes róticas e o grupo ao qual as participantes pertenciam monolíngues ou bilíngues. Dada a natureza qualitativa das variáveis, o teste selecionado foi Qui-Quadrado. Entretanto, como o desequilíbrio entre as amostras poderia fazer com que esse teste perdesse robustez de análise, foi utilizado complemento de Qui-Quadrado com resíduos padronizados. Os resíduos traçam uma comparação entre a contagem observada na amostra e a contagem esperada, definida com base nos valores totais da análise. Os resultados são considerados significativos quando o valor do resíduo ultrapassa 1,96, seja positivamente, indicando que o valor observado foi maior do que o esperado, ou negativamente, indicando que o valor esperado foi superior.

\section{DESCRIÇÃO E DISCUSSÃO DOS RESULTADOS}

A fim de iniciar a análise da produção dos róticos nos grupos consonantais no português de contato com o pomerano, são apresentados, na Tabela 1, os resultados gerais do estudo, de acordo com a variante produzida e o grupo, agrupando-se os três experimentos.

8 A presente pesquisa foi submetida ao Comitê de Ética em Pesquisa (CEP) da Pontifícia Universidade Católica do Rio Grande do Sul em 26/01/2017, sendo aprovada em 22/03/2017, sob Parecer no 1978342 e Certificado de Apresentação para Apreciação Ética (CAAE) n n 64117817.1.0000.5336 
Tabela 1 - Produção das variantes róticas pelos grupos bilíngue e monolíngue

\begin{tabular}{|c|c|c|c|c|c|c|}
\hline \multirow{3}{*}{ Variante rótica produzida } & \multicolumn{6}{|c|}{ Grupo } \\
\hline & \multicolumn{2}{|c|}{ Monolíngue } & \multicolumn{2}{|c|}{ Bilíngue } & \multicolumn{2}{|c|}{ Total } \\
\hline & $\mathrm{N}$ & $\%$ & $\mathrm{~N}$ & $\%$ & $\mathrm{~N}$ & $\%$ \\
\hline Tepe & 1022 & $91,3 \%$ & 835 & $79,4 \%$ & 1857 & $85,5 \%$ \\
\hline Aproximante alveolar & 15 & $1,3 \%$ & 48 & $4,6 \%$ & 63 & $2,9 \%$ \\
\hline Retroflexa & 1 & $0,1 \%$ & 9 & $0,9 \%$ & 10 & $0,5 \%$ \\
\hline Fricativa velar & 0 & $0,0 \%$ & 1 & $0,1 \%$ & 1 & $0,0 \%$ \\
\hline Fricativa palato-alveolar desvozeada & 6 & $0,5 \%$ & 31 & $2,9 \%$ & 37 & $1,7 \%$ \\
\hline Tepe fricatizado & 1 & $0,1 \%$ & 8 & $0,8 \%$ & 9 & $0,4 \%$ \\
\hline Ausência de evento acústico & 1 & $0,1 \%$ & 6 & $0,6 \%$ & 7 & $0,3 \%$ \\
\hline Fricativa palato-alveolar vozeada & 10 & $0,9 \%$ & 17 & $1,6 \%$ & 27 & $1,2 \%$ \\
\hline Vibrante múltipla & 62 & $5,5 \%$ & 97 & $9,2 \%$ & 159 & $7,3 \%$ \\
\hline Líquida alveolar lateral & 1 & $0,1 \%$ & 0 & $0,0 \%$ & 1 & $0,0 \%$ \\
\hline
\end{tabular}

Fonte: o autor (2020)

A Tabela 1 indica similaridades entre os dois grupos. Inicialmente, verifica-se uma ampla preferência, tanto por monolíngues quanto por bilíngues, pelo emprego do tepe como a variante rótica prototípica. Ainda que essa semelhança intergrupal seja detectada, os índices absoluto e médio revelam que as monolíngues empregam essa variável de maneira mais recorrente $(91,3 \%)$ do que as bilíngues. Por outro lado, o emprego das demais variantes róticas é sempre superior pelas bilíngues, destacando-se a produção da vibrante múltipla $(9,2 \%)$ e da aproximante alveolar (4,6\%). O grupo monolíngue igualmente faz uso dessas variantes, embora de maneira menos regular.

Um fenômeno a ser salientado é o emprego de variantes fricatizadas pelos dois grupos, especialmente na posição pós-vocálica. $\mathrm{Na}$ análise dos dados, foi detectado o emprego de quatro segmentos fricatizados, a saber: fricativa velar (1 ocorrência), fricativa palato-alveolar desvozeada (37 ocorrências), tepe fricatizado ( 9 ocorrências) e fricativa palato-alveolar vozeada (27 ocorrências). A distinção entre as palato-alveolares e os tepes fricatizados, embora de difícil estabelecimento, foi determinada com base na anterioridade da obstrução: enquanto as palato-alveolares caracterizam-se por uma obstrução mais posterior, os tepes fricatizados ocorrem na região alveolar, assemelhando-se, por um lado, ao próprio tepe e, por outro lado, à aproximante alveolar, embora demonstrando regiões de fricção da passagem de ar que deixavam marcas acústicas consideráveis nas regiões de alta frequência do espectrograma. Por fim, definiu-se como ausência de evento acústico aquelas variantes não perceptíveis com base na outiva e cujos reflexos tampouco eram detectáveis na análise acústica.

A preferência das participantes monolíngues pelo uso do tepe fica evidenciado se lançarmos um olhar mais aprofundado sobre os dados individuais das falantes desse grupo, o que pode ser realizado na Tabela 2. 
Tabela 2 - Produção das variantes pelas participantes monolíngues

\begin{tabular}{|c|c|c|c|c|c|c|}
\hline \multirow{2}{*}{ Variante rótica produzida } & \multicolumn{5}{|c|}{ Participante } & \multirow{2}{*}{ Total } \\
\hline & $\mathbf{A}$ & $\mathbf{E}$ & I & $\mathbf{M}$ & $\mathbf{R}$ & \\
\hline Tepe & 183 & 176 & 209 & 246 & 208 & 1.022 \\
\hline Aproximante & 3 & 7 & 3 & 1 & 1 & 15 \\
\hline Retroflexa & 0 & 1 & 0 & 0 & 0 & 1 \\
\hline Fricativa palato-alveolar desvozeada & 4 & 1 & 1 & 0 & 0 & 6 \\
\hline Tepe fricatizado & 0 & 1 & 0 & 0 & 0 & 1 \\
\hline Ausência de evento acústico & 0 & 0 & 0 & 1 & 0 & 1 \\
\hline Fricativa palato-alveolar vozeada & 7 & 0 & 1 & 2 & 0 & 10 \\
\hline Vibrante múltipla & 5 & 45 & 4 & 2 & 6 & 62 \\
\hline Líquida alveolar lateral & 1 & 0 & 0 & 0 & 0 & 1 \\
\hline Total & 203 & 231 & 218 & 252 & 215 & 1.119 \\
\hline
\end{tabular}

Fonte: o autor (2020)

A Tabela 2 revela que, ainda que o fator idade tenha sido uniformizado a partir da adoção de falantes com mais de 42 anos, as diferenças de idade remanescentes não podem ser desconsideradas. Essa observação justifica-se ao verificar que a participante E, a de maior idade entre todas participantes do estudo (69 anos) - como pode ser verificado no Quadro 2 -, apresenta um comportamento peculiar em relação às demais falantes. Essa participante faz uso regular da vibrante múltipla, que constitui 19,5\% dos róticos empregados. Dessas produções, a maior parcela ocorre em posição pós-vocálica (43 produções), posição na qual essa variante é empregada em 41,3\% das ocorrências, pouco menos que o tepe, que é empregado em 50,0\% das produções. Dessa forma, são recorrentes, por parte dessa participante, produções como ['karga], ilustrada na Figura 3, nas quais são verificadas, após o evento acústico correspondente à vogal tônica [a], etapas de redução de amplitude de onda - indicadas, na figura, por $\mathrm{R}$ - intercaladas por eventos acústicos de maior amplitude - destacados e sinalizados, na figura, como A, de abertura.

Figura 3 - Produção de ['karga] pela participante E

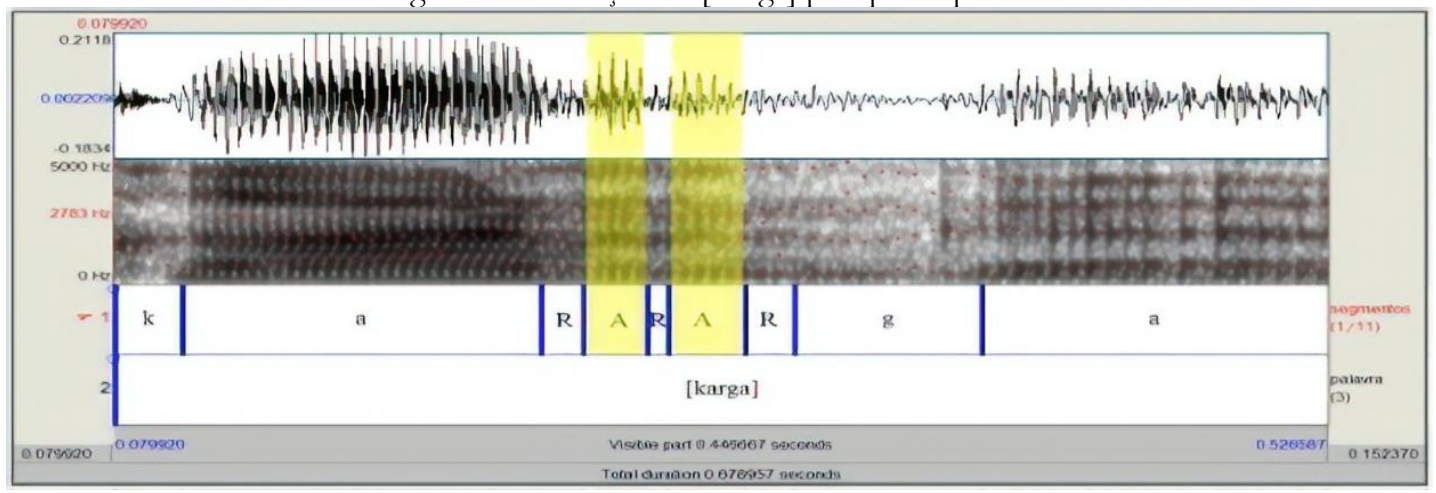

Fonte: O autor (2020) 
A análise das produções da participante E, monolíngue, conduz a três conclusões. Em primeiro lugar, ressalta que a variável idade é importante para a produção dos segmentos róticos no português brasileiro. Essa conclusão ampara-se em discussões propostas por autores como Botassini (2011), a qual, tomando como base dados do Projeto Atlas Linguístico do Brasil (ALIB), verifica a influência da variável faixa etária na produção de róticos pós-vocálicos na fala de Porto Alegre (RS). A autora identifica favorecimento no uso da vibrante múltipla alveolar pelos participantes com idades entre 50 e 65 anos e favorecimento do tepe pelos participantes com idades entre 18 e 30 anos. Monaretto (2014), reforçando essa observação, afirma haver uma tendência ao desaparecimento da vibrante múltipla, "forma antiga na língua" (MONARETTO, 2014, p. 131), na posição pré-vocálica, constituindo um processo de mudança em progresso. Logo, a produção das vibrantes múltiplas pela falante E parece estar relacionada com sua idade, constituindo um fenômeno de mudança linguística em tempo aparente.

A segunda conclusão possibilitada pela análise dos dados de E é que a produção dos tepes pelos monolíngues de Pelotas parece ainda mais maciça do que permite inferir a Tabela 1, dado que, como vimos, a produção das vibrantes por essa participante parece motivada por uma variável social, a idade. Caso excluíssemos as produções dessa participante, e a interpretássemos como um outlier, teríamos um índice de produção dos tepes pelas monolíngues de $95,3 \%$, reforçando ainda mais a prototipicidade dessa variante para o grupo.

Por fim, a análise da participante $\mathrm{E}$ nos conduz a uma terceira conclusão: há necessidade de realizar uma investigação que leve em consideração os dados pré-vocálicos e pós-vocálicos separadamente, pois o comportamento dos róticos parece ser afetado pela posição que ocupa na sílaba. Para tanto, a Tabela 3 apresenta as variantes empregadas na posição pré-vocálica, acompanhadas do resultado do Teste de Qui-Quadrado com resíduos padronizados. 
Tabela 3 - Produção das variantes róticas por grupo - posição pré-vocálica

\begin{tabular}{|c|c|c|c|c|}
\hline \multirow{2}{*}{\multicolumn{2}{|c|}{ Variante rótica produzida }} & \multicolumn{2}{|c|}{ Grupo } & \multirow{3}{*}{$\begin{array}{l}\text { Total } \\
1.134\end{array}$} \\
\hline & & \multirow{2}{*}{$\begin{array}{r}\text { Monolíngues } \\
594\end{array}$} & \multirow{2}{*}{$\begin{array}{r}\text { Bilíngues } \\
540\end{array}$} & \\
\hline \multirow{2}{*}{ Tepe } & Contagem & & & \\
\hline & Res. Padron. & 0,1 & 0,1 & \\
\hline \multirow{2}{*}{ Aproximante } & Contagem & 2 & 7 & 9 \\
\hline & Res. Padron. & $-1,2$ & 1,3 & \\
\hline \multirow{2}{*}{ Retroflexa } & Contagem & 0 & 0 & 0 \\
\hline & Res. Padron. & & & \\
\hline \multirow{2}{*}{ Fricativa velar } & Contagem & 0 & 0 & 0 \\
\hline & Res. Padron. & & & \\
\hline \multirow{2}{*}{ Fricativa palato-alveolar desvoz. } & Contagem & 2 & 0 & 2 \\
\hline & Res. Padron. & 0,9 & $-1,0$ & \\
\hline \multirow{2}{*}{ Tepe fricatizado } & Contagem & 1 & 2 & 3 \\
\hline & Res. Padron. & $-0,4$ & 0,5 & \\
\hline \multirow{2}{*}{ Ausência de evento acústico } & Contagem & 0 & 4 & 4 \\
\hline & Res. Padron. & $-1,4$ & 1,5 & \\
\hline \multirow{2}{*}{ Fricativa palato-alveolar vozeada } & Contagem & 0 & 0 & 0 \\
\hline & Res. Padron. & & & \\
\hline \multirow{2}{*}{ Vibrante múltipla } & Contagem & 2 & 2 & 4 \\
\hline & Res. Padron. & 0,4 & $-0,4$ & \\
\hline \multirow{2}{*}{ Líquida alveolar lateral } & Contagem & 1 & 0 & 1 \\
\hline & Res. Padron. & 0,7 & $-0,7$ & \\
\hline Total & Contagem & 602 & 555 & 1.157 \\
\hline
\end{tabular}

Fonte: $\mathrm{O}$ autor (2020)

A Tabela 3 demonstra que o tepe é empregado de maneira considerável na posição pré-vocálica tanto por monolíngues (98,7\% das ocorrências) quanto por bilíngues (97,3\% das ocorrências). Em um universo de 1.157 produções, apenas 23 não foram tepes, sendo as mais consideráveis as aproximantes (9 ocorrências), as vibrantes múltiplas (4 ocorrências) e as ausências de evento acústico (4 ocorrências). A análise estatística, amparada nos critérios apresentados na seção 3, não revelou qualquer correlação entre variante empregada e grupo, o que comprova o comportamento similar de monolíngues e bilíngues.

Tal similaridade não é igualmente verificada na posição pós-vocálica, como o comprova a Tabela 4. 
Tabela 4 - Produção das variantes róticas por grupo - posição pós-vocálica

\begin{tabular}{|c|c|c|c|c|}
\hline \multirow{2}{*}{\multicolumn{2}{|c|}{ Variante rótica produzida }} & \multicolumn{2}{|c|}{ Grupo } & \multirow{3}{*}{$\begin{array}{r}\text { Total } \\
720\end{array}$} \\
\hline & & \multirow{2}{*}{$\begin{array}{r}\text { Monolíngues } \\
428\end{array}$} & \multirow{2}{*}{$\begin{array}{r}\text { Bilíngues } \\
292\end{array}$} & \\
\hline \multirow{2}{*}{ Tepe } & Contagem & & & \\
\hline & Res. Padron. & 3,1 & $-3,2$ & \\
\hline \multirow{2}{*}{ Aproximante } & Contagem & 13 & 41 & 54 \\
\hline & Res. Padron. & $-2,8$ & 2,8 & \\
\hline \multirow{2}{*}{ Retroflexa } & Contagem & 1 & 9 & 10 \\
\hline & Res. Padron. & $-1,8$ & 1,8 & \\
\hline \multirow{2}{*}{ Fricativa velar } & Contagem & 0 & 1 & 1 \\
\hline & Res. Padron. & $-0,7$ & 0,7 & \\
\hline \multirow{2}{*}{ Fricativa palato-alveolar desvoz. } & Contagem & 4 & 31 & 35 \\
\hline & Res. Padron. & $-3,3$ & 3,3 & \\
\hline \multirow{2}{*}{ Tepe fricatizado } & Contagem & 0 & 6 & 6 \\
\hline & Res. Padron. & $-1,7$ & 1,8 & \\
\hline \multirow{2}{*}{ Ausência de evento acústico } & Contagem & 1 & 2 & 3 \\
\hline & Res. Padron. & $-0,4$ & 0,4 & \\
\hline \multirow{2}{*}{ Fricativa palato-alveolar vozeada } & Contagem & 10 & 17 & 27 \\
\hline & Res. Padron. & $-1,0$ & 1,0 & \\
\hline \multirow{2}{*}{ Vibrante múltipla } & Contagem & 60 & 98 & 158 \\
\hline & Res. Padron. & $-2,2$ & 2,2 & \\
\hline Total & Contagem & 517 & 497 & 1.014 \\
\hline
\end{tabular}

$\mathrm{Na}$ Tabela 4, verifica-se que monolíngues e bilíngues percorrem caminhos opostos quanto às variantes róticas empregadas. Ainda que o tepe tenha sido a variante mais produzida, as monolíngues a utilizam de maneira significativamente superior $(82,8 \%$ das ocorrências) às bilíngues (58,8\%). O Teste de Qui-Quadrado com resíduos padronizados detectou uma correlação positiva entre o grupo monolíngue e o emprego do tepe (resíduos padronizados $>1,96$ ), bem como uma correlação negativa entre o grupo bilíngue e o emprego da mesma variante (resíduos padronizados $<1,96$ ).

Por outro lado, percebe-se que as bilíngues empregaram todas as demais variantes de maneira superior, com destaque para a produção das vibrantes múltiplas $(19,9 \%$ das ocorrências), das aproximantes (8,6\% das ocorrências) e das fricativas palato-alveolares desvozeadas (6,2\% das ocorrências), o que levou o teste de Qui-Quadrado com resíduos padronizados a detectar uma correlação positiva entre o grupo bilíngue e o emprego dessas variantes. As monolíngues, por sua vez, igualmente produziram vibrantes múltiplas $(11,6 \%$ das ocorrências), aproximantes $(2,5 \%$ das ocorrências) e fricativas palatoalveolares desvozeadas (1,9\% das ocorrências), mas com números inferiores, a ponto de revelar uma correlação estatística negativa com o emprego dessas variantes. 
Diferentemente do grupo monolíngue, em que os dados de uma participante (E) constituem os outliers quanto ao uso da vibrante múltipla, no grupo bilíngue não há uma falante específica responsável por alterar de maneira considerável a média do grupo. Pelo contrário, o emprego de variantes róticas que não o tepe se dá de maneira generalizada, ainda que com discrepâncias individuais. O Gráfico 1 explicita essa informação.

Gráfico 1 - Emprego das variantes róticas pelas participantes bilíngues na posição pós-vocálica

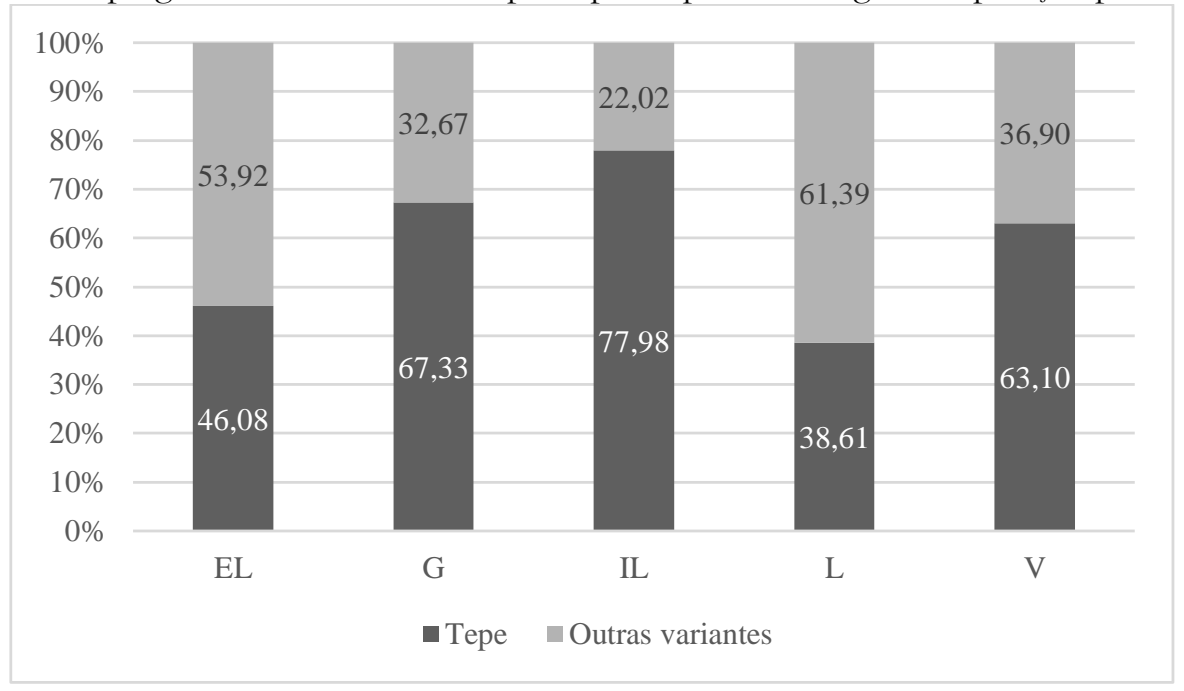

Fonte: o autor (2020)

O Gráfico 1 revela que a relação estabelecida entre o emprego do tepe e das demais variantes róticas não é desequilibrada devido à atuação de uma participante específica. Assim, verifica-se que duas falantes produzem menos tepes do que outras variantes - EL e L-, enquanto três falantes produzem mais tepes $-G$, IL e V. A única falante cujo índice de produção de tepes afasta-se da média do grupo $(58,8 \%)$ é IL, que emprega essa variante em 77,98\% das ocorrências. Ainda assim, verifica-se que o emprego das variantes róticas dá-se de maneira generalizada, e os índices obtidos na Tabela 4 não são motivados por outliers. A descrição completa das variantes róticas empregadas pelas falantes bilíngues pode ser observada na Tabela 5. 
Tabela 5 - Produção das variantes pelas participantes bilíngues na posição pós-vocálica

\begin{tabular}{r|r|r|r|r|r|r}
\hline \multirow{2}{*}{ Variante rótica produzida } & \multicolumn{5}{|c|}{ Participante } & \multirow{2}{*}{ Total } \\
\cline { 2 - 7 } Tepe & EL & G & IL & L & V & \\
Aproximante & 0 & 17 & 85 & 39 & 53 & 292 \\
Retroflexa & 1 & 0 & 0 & 6 & 2 & 41 \\
Fricativa velar & 0 & 0 & 0 & 1 & 0 & 1 \\
Fricativa palato-alveolar desvozeada & 1 & 9 & 5 & 10 & 6 & 31 \\
Tepe fricatizado & 6 & 0 & 0 & 0 & 0 & 6 \\
Ausência de evento acústico & 0 & 1 & 0 & 0 & 1 & 2 \\
Fricativa palato-alveolar vozeada & 0 & 3 & 6 & 3 & 5 & 17 \\
Vibrante múltipla & 47 & 3 & 12 & 30 & 6 & 98 \\
Total & 102 & 101 & 109 & 101 & 84 & 497 \\
\hline
\end{tabular}

Fonte: $\mathrm{O}$ autor (2020)

$\mathrm{Na}$ Tabela 5, destacam-se as produções de vibrantes múltiplas pela participante EL, que produz igual número dessa variante e de tepes (47 ocorrências). No caso da participante L, destaca-se a produção de aproximantes (30 ocorrências), número aproximado ao de produções do tepe (39 ocorrências). Essas duas participantes, dessa forma, realizam o menor número de tepes, diversificando suas produções. Por outro lado, conforme descrito no Gráfico 1, IL apresenta o maior número de tepes (85 ocorrências), produzindo, entretanto, 12 ocorrências de vibrantes múltiplas. Por fim, G e V, embora produzam um número superior de tepes (68 e 53 ocorrências, respectivamente), empregam de maneira constante aproximantes e fricativas palato-alveolares desvozeadas.

A Tabela 5 demonstra que o emprego da vibrante múltipla ocorre de maneira frequente pelas falantes bilíngues, assim como havia sido verificado nas produções da falante E. Por esse motivo, foi realizada uma análise acústica detalhada dessa variante, buscando caracterizar sua produção. Em primeiro lugar, verificou-se uma média de 2,27 batidas de ponta de língua pelas monolíngues e 2,57 pelas bilíngues. A duração média dos períodos de redução do sinal acústico - causados pelos momentos de fechamento do trato articulatório - foi de 16,39ms pelas monolíngues e de 21,50ms pelas bilíngues, enquanto a duração média dos períodos de abertura do sinal acústico - causados pela abertura do trato articulatório - foi de 24,76ms pelas monolíngues e de 23,20ms pelas bilíngues. Esses resultados indicam que as participantes bilíngues realizam, em média, um maior número de vibrações, com períodos de fechamento mais longos e com elementos vocálicos intercalados mais curtos do que as monolíngues. Os resultados indicam, ainda, coerência com os padrões descritos para o espanhol por Quilis (1999), segundo o qual a duração média do fechamento é de $20 \mathrm{~ms}$, enquanto a duração média da abertura é de $29 \mathrm{~ms}$.

Dentre essas produções, chamam atenção algumas produções que constituíram exceções a esses padrões gerais, mas que reforçam a predileção das bilíngues pelas vibrantes. Um desses casos é detalhado nas Figuras 4 e 5. 
Figura 4 - Produção da palavra borgo pela participante I (bilíngue) no experimento de leitura de palavras

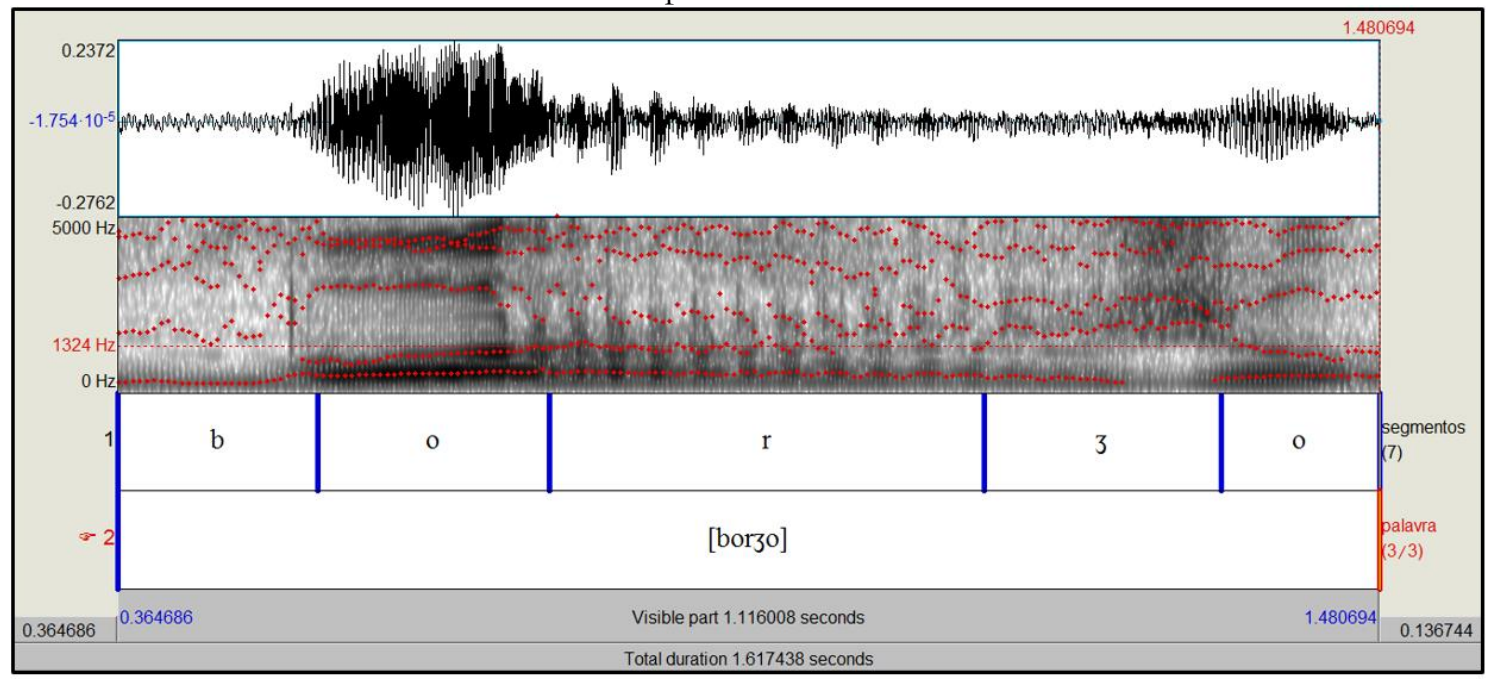

Fonte: O autor (2020)

Figura 5 - Produção destacada da vibrante na produção borgo pela participante I (bilíngue)

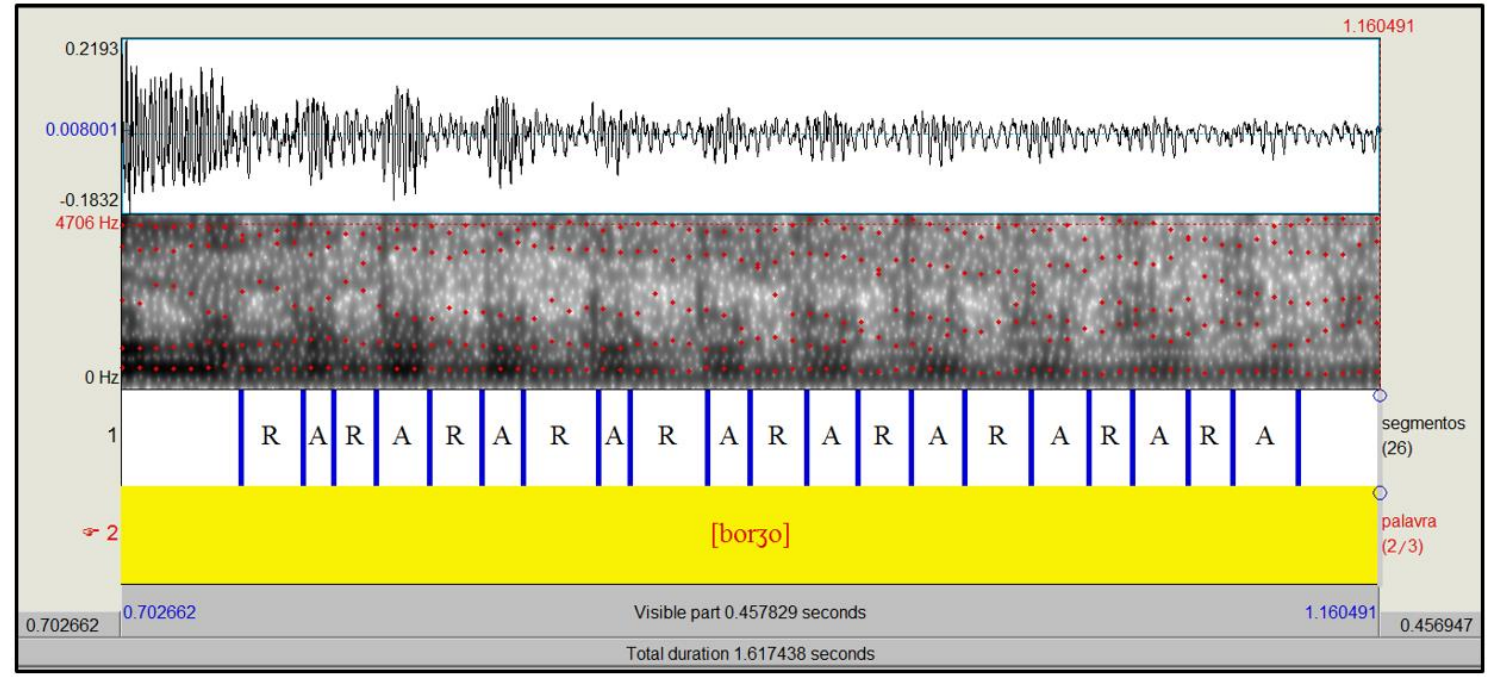

Fonte: O autor (2020)

No experimento leitura de palavras, a participante I, do grupo bilíngue, produziu a palavra "borgo" com uma vibrante dotada de dez batidas de ponta de língua e uma duração de 38,44ms. Tais produções não foram verificadas de forma recorrente, entretanto. Uma possível explicação para o alongamento realizado pela participante nessa produção específica é uma tentativa de ganhar tempo na leitura do grafema seguinte, "g", que, no português, pode ser produzido como fricativa palato-alveolar vozeada quando seguido de "e" e "i" e como uma oclusiva velar vozeada quando seguido das demais 
vogais. A confusão da participante fica evidenciada em sua produção, que ocorre com a fricativa, quando deveria ter sido utilizada a oclusiva. Tal fenômeno serve como um indício da importância de considerar-se o experimento como uma variável relevante na coleta de dados, já que cada instrumento demanda processos cognitivos diversos, que podem exercer influência nos detalhes fonéticos produzidos. Além disso, exemplifica a consistência na produção da vibrante pelas bilíngues.

\section{INTERPRETAÇÃO DOS RESULTADOS E CONCLUSÕES}

Os resultados apresentados indicam um comportamento diferenciado dos róticos a depender da posição silábica que ocupam. Em posição pré-vocálica, nota-se que o tepe é a variante mais recorrentemente produzida tanto por monolíngues quanto por bilíngues. Em posição pós-vocálica, por outro lado, o comportamento dos grupos distancia-se. Enquanto as monolíngues permanecem utilizando o tepe como variante prototípica - à exceção da participante $\mathrm{E}$-, as bilíngues empregam diferentes variantes róticas, como vibrantes múltiplas, aproximantes e fricativas palato-alveolar desvozeadas.

A variabilidade detectada apenas na posição pós-vocálica parece encontrar respaldo na comparação estrutural do contato linguístico entre português e pomerano. Conforme observado na seção 2, o pomerano não apresenta tepes em posição de coda simples, ao contrário do que ocorre no português falado no município de Pelotas. Assim, a lacuna verificada na comparação entre as línguas parece incentivar as falantes bilíngues, que tem o pomerano como língua dominante, a empregar variantes outras, que não o tepe, nessa posição. A ocorrência de variantes fricativas, nesse sentido, parece ir ao encontro do verificado no sistema fonológico do pomerano, que apresenta fricativas - embora mais posteriores - na posição de coda.

Por outro lado, o considerável número de vibrantes múltiplas na fala das bilíngues parece não ser motivado por diferenças estruturais entre as duas línguas, dado que o pomerano igualmente não apresenta essa variante em seu inventário na posição de coda. Dado o fenômeno da neutralização entre vibrantes simples e múltiplas verificado por autores como Prade (2003), parece que a vibrante múltipla apresenta-se como uma variedade regional da fala de teuto-brasileiros, não apenas nos de origem pomerana. Cabe compreender os significados estruturais e sociais que perpassam o uso dessa variante, um objetivo que o presente trabalho não é capaz de alcançar, tornando-o um encaminhamento futuro.

De qualquer forma, a presente pesquisa revelou um novo comportamento dos falantes bilíngues do pomerano e português quanto à produção dos róticos. Se trabalhos como Prade (2003), Vandresen (2006) e Bilharva da Silva (2015) discutiram a questão da neutralização entre vibrantes como um traço característico desse grupo social, foram oferecidos indícios de que também há um comportamento peculiar quanto à produção dos róticos em posição pós-vocálica, na qual esses falantes empregam um índice de tepes inferior a falantes monolíngues do português.

Importante salientar também que o estudo de um contexto linguístico não contrastivo no português permitiu a observação de influências mais claras do pomerano, dado que a alofonia presente nesta posição não cria restrições para que o falante realize 
variações fonéticas, possivelmente influenciadas pela língua dominante. Ou seja, não havendo contrastividade entre as variantes róticas na posição de coda, o falante não busca evitar influências da língua dominante, dado que essas influências não implicam em mudanças semânticas na língua alvo. Dessa forma, ressalta-se a importância de os estudos linguísticos investigarem não apenas aspectos concernentes à fonologia das línguas, mas igualmente a aspectos fonéticos, que podem muitas vezes revelar fenômenos mais claros relacionados ao contato linguístico.

\section{REFERÊNCIAS}

BENINCÁ, L. Dificuldades no dominio de fonemas do português por crianças bilíngues de português e pomerano. 2008. Dissertação (Mestrado em Letras). Universidade Federal do Espírito Santo.

BILHARVA DA SILVA, F. Produção oral e escrita dos róticos em Arroio do Padre (RS): avaliando a relação português/pomerano com base na Fonologia Gestual. 2015. Dissertação (Mestrado em Letras) - Programa de Pós-Graduação em Letras, Universidade Federal de Pelotas.

BILHARVA DA SILVA, F. O contato português-pomerano na produção dos grupos [Cr] e [rC]: o caso das vogais suarabácticas. 2019. 279 f. Tese (Doutorado em Linguística) - Escola de Humanidades, Pontifícia Universidade Católica do Rio Grande do Sul.

BONILHA, Giovana Ferreira Gonçalves. Aquisição fonológica do Português Brasileiro: uma abordagem conexionista da teoria da otimidade. 2005. 389 f. Tese (Doutorado em Linguística Aplicada) - Faculdade de Letras, Pontifícia Universidade Católica do Rio Grande do Sul, Porto Alegre.

BOTASSINI, J. O. M. A variação no uso dos róticos em Porto Alegre. Estudos linguísticos, São Paulo, 40 (2): p. 1060-1072, mai-ago 2011.

BREMENKAMP, E. S. Análise sociolinguística da língua pomerana em Santa Maria do Jetibá, Espirito Santo. 2014. 293 p. Dissertação (Mestrado em Estudos Linguísticos) - Centro de Ciências Humanas e Naturais, Universidade Federal do Espírito Santo, Vitória, 2014.

BREMENKAMP, E. S.; RYS, K.; NEVINS, A.; POSTMA, G. Zeeuws-Flemish in Brazil: multilingualism and language decay. Gragoatá, Niterói, v. 22, n. 42, p. 435-472, jan.-abr. 2017

CUNHA, J. L. A Alemanha e seus emigrantes: questões nacionais. In: CUNHA, J. L.; GÄRTNER, A. (orgs.). Imigração alemã no Rio Grande do Sul: História, Linguagem, Educação. Santa Maria: UFSM, 2003. 
FERGUSON, C. A. Diglossia, WORD, 15:2, p. 325-340, 1959. DOI: 10.1080/00437956.1959.11659702.

FISHMAN, J. A. Sociologia del language. Tradução de Ramón Sarmiento y Juan Carlos Moreno. Madrid: Catedra, 1979.

GROSJEAN, F. Studying bilinguals. Oxford: Oxford University Press, 2008.

GROSJEAN, F. Bilingual: life and reality. Cambridge: Harvard University, 2010. https://doi.org/10.4159/9780674056459

INSTITUTO BRASILEIRO DE GEOGRAFIA E ESTATÍSTICA. Brasil: 500 anos de povoamento. Rio de Janeiro, 2000. Apêndice: Estatísticas de povoamento. p. 225.

MATRAS, Y. Universals of linguistic borrowing. In: SIEMUND, P. Linguistic universals and language variation. Berlim: Mouton, 2011, p. 200-229.

MATZENAUER, C. L. B.; BONILHA, G. F. G. Aquisição da Fonologia e Teoria da Otimidade. Pelotas: EDUCAT, 2003.

MIRANDA, A. R. M. A aquisição do ' $r$ ': uma contribuição à discussão sobre seu status fonológico. 1996. 128 f. Dissertação (Mestrado em Letras) - Pontifícia Universidade Católica do Rio Grande do Sul - PUCRS, Porto Alegre.

MONARETTO, V. Realizações de R. In: BISOL, L.; BATTISTI, E (Org.). O português falado no sul do Brasil. Porto Alegre: EDIPUCRS, 2014.

PIKE, K. L. Phonemics: a technique for reducing languages to writing. Ann Arbor: The University of Michigan Press, 1947.

PRADE, H. G. O linguajar do alemão gaúcho. In: CUNHA, J. L.; GÄRTNER, A. (Org.). Imigração alemã no Rio Grande do Sul: História, Linguagem, Educação. Santa Maria: UFSM, 2003.

QUILIS, A. Tratado de fonologia y fonética españolas. 2 ed. Madrid: Gredos, 1999. 558 p.

REINECKE, K. Os róticos intervocálicos na gramática individual de falantes de Blumenau e Lages. 2006. 241 p. Tese (Doutorado em Letras) - Centro de Comunicação e Expressão, Programa de Pós-graduação em Linguística, 2006.

RIO GRANDE DO SUL. In: WIKIPÉDIA, a enciclopédia livre. Flórida: Wikimedia Foundation, $2019 . \quad$ Disponível em: https://pt.wikipedia.org/w/index.php?title=Rio_Grande_do_Sul\&oldid=56745903. Acesso em: 16 nov. 2019. 
RÖLKE, R. H. Descobrindo raízes: aspectos geográficos, históricos e culturais da Pomerânia. Vitória: UFES, 1996, 123 p.

ROMERO, J. Gestural timing in the perception of Spanish $\mathrm{r}+\mathrm{C}$ clusters. Selected Proceedings of the 3rd Conference on Laboratory Approaches to Spanish Phonology, p. 59-71, 2008.

SCHAEFFER, S. C. B. Descrição fonética e fonológica do pomerano falado no Espírito Santo. 2012. 130 f. Dissertação (Mestrado em Linguística) - Faculdade de Letras, Universidade Federal do Espírito Santo, 2012.

TRESSMANN, I. Bilinguismo no Brasil: o caso da comunidade pomerana de Laranja da Terra. Associação de Estudos da Linguagem (ASSEL-Rio), Universidade Federal do Rio de Janeiro - UFRJ, Rio de Janeiro, 1998.

VANDRESEN, P. Contato linguístico e bilinguismo em Arroio do Padre. Encontro do Círculo de Estudos Linguísticos do Sul-CELSUL, 7, 2006, Pelotas, RS.

MATZENAUER, Carmen L. B. et al (Orgs.). Anais... Pelotas: EDUCAT, 2008. pp. 1-6. Disponível em http://www.celsul.org.br/Encontros/07/dir2/1.pdf. Acesso em 14 fev. 2014.

WEINREINCH, U. Languages in contact. The Hague: Mouton Publishers, 1963 [1953]. 148 p.

YAVAS, M.; HERNANDORENA, C. L. M.; LAMPRECHT, R. R. Avaliação fonológica da criança. Porto Alegre: Artes Médicas, 1991. 